\title{
Solutions for the Accessibility of Water Sources for Fire Extinguishment
}

\author{
Gergely HERCZEG ${ }^{1}$, Ágoston RESTÁS²
}

\begin{abstract}
Water is an essential fire extinguishing agent. Besides the existence of water for this purpose, the availability of water sources is essential as well. Quick and efficient access to water sources contributes to effective firefighting, thereby avoiding any increase in damage, and it protects human life. With regard to the water sources, the authors examine and analyse the anthropometric data, and the physical properties of the equipment needed for the water. These are also used to determine the conditions of optimal access to the various water sources for firefighting.
\end{abstract}

Keywords: water sources for firefighting, fire hydrant, water sources, accessibility, fire intervention requirements.

\section{Introduction}

Water is an essential extinguishing agent during firefighting. In addition to the availability of water for fire extinguishment, it is also essential to have access to water sources, during firefighting, revision and maintenance. Accessibility is determined, on the one hand, by the characteristics of the human body and, on the other hand, by the physical properties of the devices required for the water. At this time, we do not know under what conditions the fire protection equipment and the water sources for fire extinguishment are available (taking into account e.g. anthropometric features). In some cases, the current regulations formulate only a general requirement for accessibility. However, they do not always provide guidelines on the implementation, which is of specific nature. The author aims to determine the conditions required for the availability of the water sources.

According to the author, fire hydrants, water storage tanks, wall fire hydrants can be considered as water sources. There are currently only a few Hungarian and international publications on the topic. However, we can find several papers in international and national literature on the topic of ergonomics and anthropometry. In many cases, these publications also deal with the authors' broader field of expertise, but they are not explicitly concerned with the relationship between water sources and humans. They deal with the conditions for

1 Doctoral student, National University of Public Service, Faculty of Military Sciences and Officer Training, Doctoral School of Military Engineering; e-mail: herczeggergely@gmail.com; ORCID: https://orcid.org/00000001-9633-5152

2 Ph.D., associate professor, National University of Public Service; e-mail: restas.agoston@uni-nke.hu; ORCID: https://orcid.org/0000-0003-4886-0117 
quick use and easy access to the water sources for firefighting. Otherwise, these publications deal only with the authors' narrow field of expertise. Typically, standards or guidelines deal with this topic. [1, 2] There are only a few articles that refer to the technical tools used for salvage by water.

Scientific research is essential in fire prevention to increase efficiency, decrease injuries, and to maximise the rescued value. [3: 159] Nowadays, engineering comes into view increasingly in fire protection. [4]

Because of the reasons mentioned above, this paper can be suppletory, as it attempts to present data that contributes to the sufficient availability of the water sources for firefighting. Based on data, methods, and principles that can be found in the Hungarian and international literature, the author has developed suggestions that help to determine the necessary parameters for the availability of water sources. During the research, the author analysed the relevant national and international literature, including standards and other documents. The authors study and compare national and international literature as well as various standards and guidelines, and through this comparative analysis they will formulate suggestions for the accessibility to water sources.

On the one hand, the literature generally mentions data related to the size of the human body, [5] and on the other hand, there are concrete suggestions that can be used in other fields that require similar technique. [6] So far, research has used anthropometric data to produce ergonomic results. However, they have focused primarily on the interaction between man, machine, and the environment, and have tried to optimise them. These studies rarely include occasional activities such as the use of water sources for firefighting.

A 2016 study suggested that a fire hydrant should be available within $100 \mathrm{~m}$ from the main entrance of the buildings, thereby increasing the $30 \mathrm{~m}$ requirement in Portugal. [7] Myburgh and Jacobs also deal with the use of fire hydrants, but not with the conditions of their availability. They conclude that it is advisable that the hydrants be as close to the fire as possible. [8] Zhou and Reniers investigated the relationship between the number of fire hydrants and the success of firefighting. They found that increasing the number of fire hydrants improves the success of firefighting. [9] Based on a questionnaire made in Taiwan, Wang and Shih stated that the most commonly used water sources for firefighting are hydrants. [10] A 2014 study dealt with the hydrodynamical optimisation of hydrants, but their research did not extend to the availability of the fire hydrants. [11] Hassanain, Hafeez, and Sanni-Anibire assessed in their study a fire hydrant with a free space of $914 \mathrm{~mm}$ and located within $122 \mathrm{~m}$ from the protected building as suitable. [12] Sierra, Rubio-Romero and Gámez point out that wall fire hydrants should be easily accessible, but they do not specify criteria for it. [13] According to J. A. Smith, firefighting areas should be first cleared from snow for easier accessibility, but he does not specify the extension required for access. [14]

One of the main areas of ergonomics is physical ergonomics. It deals with the physical activity, the structure of the human body, its dimensions, and also its biomechanical and physical characteristics. [15] Anthropometry is the science of the characteristics of the human body, which examines the dimensions, shape, power, and working capacity of the body. Anthropometry is a branch of ergonomics. [16: 6] In case of an extraordinary event or fire, the human behaviour differs from the ordinary, [17] so, in such a situation, the water sources for firefighting must be as noticeable and accessible as possible. The goal of 
the author is to facilitate the decision-making that is difficult in such a situation, and thus to provide effective firefighting.

In $97.9 \%$ of the territory of Hungary, it is guaranteed that the firefighters arrive at the fire scene in 25 minutes after the alarm. [18] If the arrival of the firefighters is suffering a delay, it is expedient if the workers of the facility make the water sources accessible prior, and it is not a task of the firefighters.

Easy access to the water source used for fire extinguishment allows a quick use. Accessibility shall be allowed to everybody who may be able to use the water source for firefighting or wants to inspect or maintain it. When water sources are accessible, the firefighting can be accomplished quickly and efficiently. When studying the current Hungarian regulations, it is not clear whether the legislator prescribes water sources for firefighting only to facilitate the intervention of the fire departments or to facilitate firefighting by non-firefighters.

The balance of the fire protection could be unstable if there are cars parking on the keep clear area around the water source. [19: 195]

Mainly wall fire hydrants with rigid hose are used in case of a fire of combustible materials that are not under voltage. Its use does not require any specific training. These can be, for example, outdoor fires, bush fires, or municipal waste container fires. It can be a good idea to designate for this task people in workplaces who are trained and able to do firefighting. [20]

Considering that the legislation prescribes water sources in order to facilitate the firefighting for non-firefighters, it is advisable that the rules of fire protection include their availability. The author examines the accessibility of water sources from the perspective of a healthy adult.

\section{Criteria of Accessibility}

We must know the anthropometric data of the potential users in order to determine the availability of some types of water sources for firefighting. We can find representative data on this in a standard. [21] Although the object of this standard is the dimensioning of the access openings used on the machines, it is nevertheless suitable for determining the availability of water sources for firefighting. The standard includes anthropometric data according to percentiles. "The $\mathrm{x} \%$ percentile of a distribution is the number less than or equal to $\mathrm{x} \%$ of the elements.” [22: 22] I always recommend the percentile that gives access to as wide a range of users as possible. Accessibility to the water source requires an unobstructed space, which is at least 2,094 $\mathrm{mm}$ high and at least $726 \mathrm{~mm}$ wide. It may also be necessary to exert more force for the use of the water sources for firefighting. The water sources demanding more force for the operation should be between $920 \mathrm{~mm}$ and 1,105 mm above the ground level. Height limits that allow less power are between 600 and 1,520 mm. [23] According to the NFPA 1142 8.4.1. (National Fire Protection Association, USA) regulation, at least $0.9144 \mathrm{~m}$ space should be held around the output manifold connections of the hydrants. [24] According to the NFPA 14 7.3.1. regulation, the centre of the closed valves for wall fire hydrants (e. g. valve, tap) shall be at least $0.9 \mathrm{~m}$ and not more than $1.5 \mathrm{~m}$ from the ground. The recommended height of the water supply stump of the dryline shall 
be between $457 \mathrm{~mm}$ and 1,219 $\mathrm{mm}$ above the ground, according to paragraph 6.4.6. [25] According to the NFPA 1 18.5.7.2. regulation, at least 1,524 mm space should be held around the hydrants having an inside diameter greater than $64 \mathrm{~mm}$. [2] According to DIN 14461-1, the height of the closed valve of the wall fire hydrant shall be 1,200-1,600 mm above the ground. [1]

One of the requirements of the fire hydrant is that they shall allow the water to safely get out, taking into account the minimum bending radius of the hose. The manufacturer does not always specify the minimum bending radius of the hose at nominal pressure. [26] According to the Q1 figure of the harmonised standard, the hoses have to be tested so that when bended, they shall lie flat between the guide rails with a radius 22 times more than their inner diameter. [27] The same is required by the relevant Hungarian standard 7.8.3. [28] A 75 mm diameter " $B$ " hose is used to supply the fire engines with water. [29]

The minimum bending radius of the outer bend of the hose " $\mathrm{B}$ ":

$$
r=\frac{22 \cdot 75 \mathrm{~mm}}{2}=825 \mathrm{~mm}
$$

A hydrant key is also required for the operation of the hydrants. The length of the ground hydrant key is about $600 \mathrm{~mm}$. When we place it on the hydrant, it describes an arc of $300 \mathrm{~mm}$ from the longitudinal axis during the opening. [30] Besides, the distance required to hold the fire key is $150 \mathrm{~mm}$, taken also into account the length of the hand. [23] So, the required space for opening the hydrant is $450 \mathrm{~mm}$ around the longitudinal axis of the hydrant.

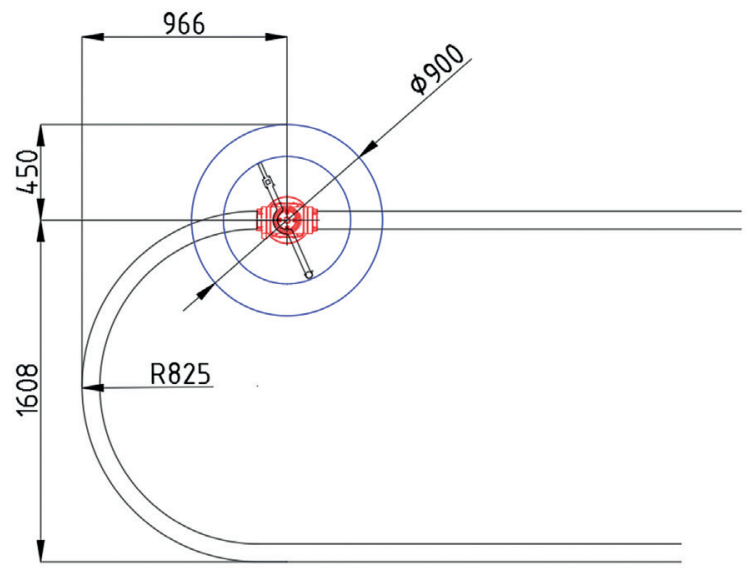

Figure 1. Ground fire hydrant with two "B” hoses, hydrant key. [Created by the author.]

Figure 1 illustrates the operational position and dimension of the devices required to operate the ground fire hydrant. Based on these dimensions, a simplified scheme of free space can be determined around the fire hydrant (Figure 2).

The free area around the fire hydrant should have a solid surface. It will ensure that in all weather conditions the traffic around the hydrant and the operation of the hydrant will be undisturbed. The slope conditions of the pavement must be suitable for people to stay and travel on it. Therefore, the limit for the maximum slope for pedestrian traffic is applicable 
here, which is $1: 8$. [31: 268] The fire hydrant should also be approached on a solid road surface. However, its width should be at least equal to the shoulder width (726 mm), [23] the slope limit of $1: 8$ is also applicable here. A solid pavement is also reasonable because, in the case of underground hydrants, if the environment of the hydrant is not rigid, the sediment deposited by watercourses formed during rainy weather may obscure the hydrant. The solid pavement around the hydrant can help to locate the hydrant under the sediment. Also, if the solid pavement is long enough in the opposite direction to the slope, it will reduce the amount of sediment. The criterion of accessibility of outdoor hydrants in winter is de-icing and snow removal. If the installation has a heated pavement, we suggest extending it to the surroundings of the water sources and the roads leading to them. If there is no heated pavement, the road leading to the water source must be de-iced continuously. [28]

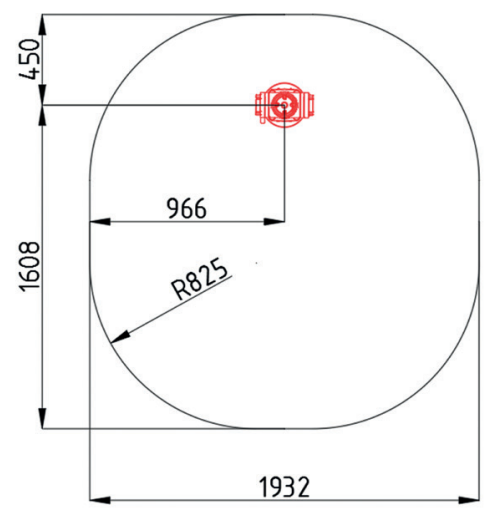

Figure 2. An illustration of the availability of an outdoor ground fire hydrant. [Created by the author.]

Suction hoses are required to extract the amount of water that we can remove from the water sources by suction. It can withstand the effects of internal pressures, which is below the atmospheric pressure. Water extraction by suction may occur when water is taken from cisterns. The connection point of the water output manifold is optimised from the perspective of human force and ergonomic design when it is positioned at the height of 920-1,105 mm. The height of the output manifold of the fire engine shall also be taken into account during the design. It is advisable to maintain a space large enough to operate the fire engine in front of the connection of the output manifold of the water source. It is necessary to take into account the dimensions of all fire engines, to ensure the accessibility to water sources.

One of the most extended water carrier vehicles in Hungary is the fire engine Heros Aquarex S10. It has a length of $8,300 \mathrm{~mm}$, a width of 2,550 mm, a height of 3,520 mm, and the maximum authorised mass of it is $25,000 \mathrm{~kg}$. [32] In the EU, the maximum width of a vehicle on the road is $2,550 \mathrm{~mm}$, the maximum allowed height is $4,000 \mathrm{~mm}$, and the maximum allowed length is $11,000 \mathrm{~mm}$. [33] When planning the open spaces and the accessibility, it is advisable to take into account the maximum permissible size of the vehicles, as this prevents subsequent modifications and extensions, which may become 
a financial burden. For the possibility of the connection of the output manifold connector and the output manifold at the rear of the vehicle, it is advisable to keep free space, at least a length of one suction hose between the connector of the water source and the rear of the vehicle. In general, a $110 \mathrm{~mm}$ diameter suction hose is used in Hungary, which is 2,000 mm long. [34] This is why the required distance is $2,000 \mathrm{~mm}$. The length of the free space in front of the output manifold connection of the water source shall be the permitted length of the vehicle, the length of the suction hose, and the total length of the space required for traffic around the vehicle (shoulder width). This value is $13,726 \mathrm{~mm}$, based on the above. The size of the free space to be provided is the permissible width of the vehicle. The protruding part of the vehicle is the size defined by the space required for free movement. Considering this, the author recommends for this value to be at least 5,000 mm. The height of the free space in front of the connection of the output manifold of the water source shall be at least equal to the sum of the maximum possible height of the vehicle plus the height of the human body with supplements. [23] This value is $6,094 \mathrm{~mm}$.

If the fire engine is installed perpendicularly to the axis of connection of the output manifold of the water source, the space required for accessibility can be determined based on the minimum bending radius of the suction hose.

The minimum required bending radius of a $110 \mathrm{~mm}$ diameter suction hose is $1,100 \mathrm{~mm}$ in Hungary. [35] In this condition, the outside of the hose bent at the minimum required bending radius shall be curved with a radius of at least $1,230 \mathrm{~mm}$. In this case, the wall thickness of the hose is ignored.

Figure 3 illustrates the horizontal dimensions of the installation site, which is perpendicular to the connection of the output manifold of the water source.

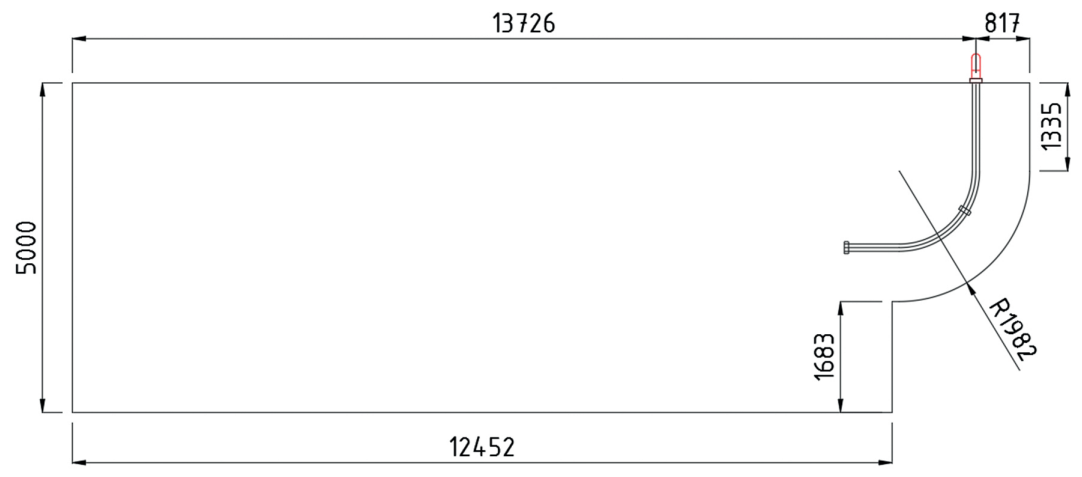

Figure 3. The size of the area around the connection of the output manifold of the water source. [Created by the author.]

\section{Summary}

The author presented data that are relevant for the equipment needed for the use of water sources for firefighting. Using these data, I determined the conditions of the availability 
G. HERCZEG, Á. RESTÁS: Solutions for the Accessibility of Water Sources for Fire...

of the water sources, primarily the horizontally free spaces around the water sources for firefight. Also, I determined the optimal height of those parts of the water source where greater force is needed, and the height of the lowest and highest points of the parts requiring less force for optimal accessibility. The solutions presented by the author can also improve the effectiveness of firefighting interventions and may be suitable for firefighting in the case of vehicle fires in land, water, and air. This paper provides an opportunity to implement general regulation by quantifying it.

For accessibility of the water sources, the authors have identified the following data, which provides access for a wide range of users, and includes rare uses:

- on the way to the water source a path 2,094 $\mathrm{mm}$ high and $726 \mathrm{~mm}$ wide should be provided;

- the lowest point of the control of the water source should be $600 \mathrm{~mm}$ from the ground (floor);

- the highest point of control of the water source should be $1,520 \mathrm{~mm}$ from the ground (floor);

- the height of the control of the water source, which requires more force, is optimal between 920 and 1,105 $\mathrm{mm}$ above the ground (floor);

- the geometric data of the space kept free around the hydrant are shown in Figure 2;

- Figure 3 shows the horizontal dimensions of the installation site, which is perpendicular to the connection of the output manifold of the water source.

The values mentioned above are primarily based on literature; they consider the dimensions of the human body and human effort. It is an everyday activity for firefighters to use water sources. However, it is a rare task for workers in a facility. Therefore, it may be useful to examine by experiments the solutions developed by the author before using the data in practice.

\section{References}

[1] DIN 14461-1:2016-10 Feuerlösch-Schlauchanschlusseinrichtungen. Teil 1: Wandhydrant mit formstabilem Schlauch. www.beuth.de/de/norm/din-14461-1/258819312 (Downloaded 30.04.2019)

[2] NFPA 1 Fire code. 2018 edition. www.nfpa.org/codes-and-standards/all-codes-andstandards/list-of-codes-and-standards/detail?code=1 (Downloaded 30.04.2019)

[3] PÁNTYA P.: Kutatási alapok a katasztrófák elleni védekezés technikai fejlesztéséhez. Hadmérnök, 121 (2017), 158-169.

[4] RESTÁS Á. - PÁNTYA P. - HORVÁTH L. - RÁCZ S. - HESZ J.: A tűzvédelem komplexitása a korszerű megelőzéstől a hatékony beavatkozásig. In RESTÁS Á. - URBÁN A. szerk.: Katasztrófavédelem. Budapest, BM OKF, 2015. 161-165.

[5] MSZ EN ISO 7250-1:2018 Az emberi test alapvető méretei múszaki tervezéshez. 1. rész: Testméret-meghatározások és mérési pontok (ISO 7250-1:2017.)

[6] MSZ EN 547-2:1996+A1:2009 Gépek biztonsága. Az emberi test méretei. 2. rész: A hozzáférési nyílások méretezésének alapelvei. 
G. HERCZEG, Á. RESTÁS: Solutions for the Accessibility of Water Sources for Fire...

[7] FERREIRA, T. M. - VICENTE, R. - DA SILVA, J. A. R. M. - VARUM, H. - COSTA, A. - MAIO, R.: Urban fire risk: Evaluation and emergency planning. Journal of Cultural Heritage, 20 (2016), 739-745. DOI: https://doi.org/10.1016/j.culher.2016.01.011

[8] MYBURGH, H. M. - JACOBS, H. E.: Water for firefighting in five South African towns. Water SA, 401 (2014), 11-18. DOI: https://doi.org/10.4314/wsa.v40i1.2

[9] ZHOU, J. - RENIERS, G.: Simulation analysis of the use of emergency resources during the emergency response to a major fire. Journal of Loss Prevention in the Process Industries, 44 (2016), 1-11. DOI: https://doi.org/10.1016/j.jlp.2016.08.007

[10] WANG, C-P. - SHIH, B-J.: Research on the Integration of Fire Water Supply. Procedia Engineering, 211 (2018), 778-787. DOI: https://doi.org/10.1016/j.proeng.2017.12.075

[11] HYUN, I.-H. - CHEON, S. - KIM, D. - SECK, D. - CHOI, S.: Improvement of Fire Hydrant Design to Enhance Water Main Flushing. Procedia Engineering, 70 (2014), 857-863. DOI: https://doi.org/10.1016/j.proeng.2014.02.094

[12] HASSANAIN, M. A. - HAFEEZ, M. A. - SANNI-ANIBIRE, M. O.: A ranking system for fire safety performance of student housing facilities. Safety Science, 92 (2017), 116-127. DOI: https://doi.org/10.1016/j.ssci.2016.10.002

[13] SIERRA, F. J. M. - RUBIO-ROMERO, J. C. - GÁMEZ, M. C. R.: Status of facilities for fire safety in hotels. Safety Science, 507 (2012), 1490-1494. DOI: https://doi.org/10.1016/j. ssci.2012.01.006

[14] SMITH, J. A.: Preparing for winter: Proactive measures to prevent injury and property damage. Professional Safety, 428 (1997), 28-32.

[15] SZABÓ Gy.: A katonai szolgálatból származó fizikai terhelés értékelésének módszerei. (Doktori értekezés) Budapest, NKE, 2013.

[16] PHEASANT, S.: Bodyspace Anthropometry, Ergonomics and the Design of Work. London, Taylor \& Francis, 2003.

[17] RESTÁS Á.: Tűzoltók szemtől szemben az érintettekkel: Viselkedésformák tűzés káreseteknél. Bolyai Szemle, 133 (2014), 25-35.

[18] BÉRCZI L. - PAPP CS. L.: A mentő tűzvédelem diszlokációja a valóságos fehér foltok függvényében. Védelem - Katasztrófavédelmi Szemle, 202 (2013), 9-11.

[19] ÉRCES G. - KOMJÁTHY L.: Mérnöki módszerek szerepe a felszíni alatti vasútvonalak tűzvédelmi helyzetének alakulásában. Hadmérnök, 134 (2018), 191-198.

[20] HAGEBÖLLING, D.: Taschenbuch betrieblicher Brandschutz. Essen, Vulkan Verlag, 1999.

[21] MSZ EN 547-3:1996+A1:2009 Gépek biztonsága. Az emberi test méretei.

3. rész: Testméretek.

[22] FIDY J. - MAKARA G.: Biostatisztika. Budapest, InforMed 2002 Kft, 2005.

[23] HERCZEG G.: Túzvédelmi eszközök optimális elhelyezésének antropometriai meghatározása. Hadmérnök, 133 (2018), 18-27.

[24] NFPA 1142 Water supplies for suburban and rural fire fighting. 2017 edition. www. nfpa.org/codes-and-standards/all-codes-and-standards/list-of-codes-and-standards/ detail?code=1142 (Downloaded 30.04.2019)

[25] NFPA 14 Installation of standpipe and hose systems. 2019 edition. www.nfpa.org/codes-andstandards/all-codes-and-standards/list-of-codes-and-standards/detail?code=14 (Downloaded 02.05.2019)

[26] HERCZEG G.: TvMI használati szabályokról I. - Tüzvédelmi eszközök hozzáférhetősége. Védelem - Katasztrófavédelmi Szemle, 235 (2016), 12-16. 
G. HERCZEG, Á. RESTÁS: Solutions for the Accessibility of Water Sources for Fire...

[27] MSZ EN 15889:2011 Tüzoltó tömlők. Vizsgálati módszerek.

[28] MSZ 1185:2016 Tûzoltó tömlők. Vízzáró lapos nyomótömlők és szerelt tömlők tüzoltó szivattyúkhoz és -járművekhez.

[29] 3/2015. (VI. 8.) BM OKF utasítás a tűzoltóságok Szerelési Szabályzatáról.

[30] MSZ 9771-3:2009 Tüzcsapok és tartozékaik. 3. rész: Túzcsapkulcsok.

[31] HANSEN, D. J.: Occupational Health Fundamentals. s. l. CRC Press, 1991.

[32] NAGY G.: Heros Aquarex S10 vízszállító gépjármú. Védelem - Katasztrófavédelmi Szemle, 261 (2019), 59-61.

[33] Council Directive 96/53/EC of 25 July 1996 laying down for certain road vehicles circulating within the Community the maximum authorized dimensions in national and international traffic and the maximum authorized weights in international traffic. Official Journal, L 235, 179 (1996), 59-75.

[34] MSZ 1078:1971 Tüzoltó szívótömlő.

[35] MSZ EN ISO 14557:2003 Tüzoltótömlő. Gumi és múanyag szívótömlők és tömlőszerelvények. 